Niepełnosprawność. Dyskursy pedagogiki specjalnej

Nr 32/2018

Disability. Discourses of special education

No. 32/2018

Dorota Krzemińska, Iwona Lindyberg

Uniwersytet Gdański

\title{
O (nie)studiowaniu i (nie) przygotowaniu do pracy w obszarze wsparcia dorosłych osób z niepełno- sprawnością. Refleksja z doświadczeń nauczyciela akademickiego i badacza
}

Prezentowany tekst jest próbą zmierzenia się z zagadnieniem (nie) przygotowania pedagogów specjalnych do podjęcia pracy w obszarze wsparcia w dorosłości i starości osób z niepełnosprawnością. Ukazujemy w nim aktualne pytania i dylematy pedagogiki specjalnej jako dyscypliny naukowej i jej podmiotu oraz kierunku kształcenia studentów, w którym dostrzegamy wyraźną lukę $\mathrm{w}$ polu zawodowej formacji kadr do pracy $\mathrm{z}$ osobami dorosłymi i seniorami z niepełnosprawnością.

Słowa kluczowe: pedagogika specjalna, kształcenie pedagogów specjalnych, dorosłość i starość z niepełnosprawnością

\section{On (not)studying and not(preparing) to support adults with disabilities. Reflecting on university teacher's and researcher's experience}

The presented paper aims to highlight some weak point in special educators' schooling which is the lack of preparation for care and support of adults with disabilities. In the text the authors rise valid questions and dilemmas of current special education as scientific discipline, as well as Bachelor's or Master's degree studies which notoriously seem to fail in special educators professional training in care and support for adults and aging people with disabilities.

Keywords: special education, special educators training, adulthood and aging with disabilities 


\section{Pytania o dorosłość z niepełnosprawnością i „jej”} profesjonalistów w polu pedagogiki specjalnej jako dyscypliny naukowej i kierunku studiowania w uczelniach wyższych

W ostatnim czasie stawianych jest wiele pytań dotyczących kondycji pedagogiki specjalnej jako dyscypliny naukowej. Jednym $\mathrm{z}$ istotnych dylematów jest oczywiście pytanie o jej podmiot. Współcześnie w centrum zainteresowania pedagogiki specjalnej znalazła się w końcu osoba w ciągłości jej biografii. Tak więc $\mathrm{w}$ ten sposób objawiła się również przestrzeń dorastania, dorosłości i starzenia się oraz starości osób z niepełnosprawnością, zaburzeniami rozwojowymi czy też doświadczających choroby. Oczywiście nie każda osoba potrzebuje wsparcia $\mathrm{w}$ tej fazie życia, jest to bowiem zależne od jej poziomu funkcjonowania, ze szczególnym uwzględnieniem samodzielności i niezależności.

Mówiąc o starzeniu się/starości osób z niepełnosprawnością za słuszne uważamy w tym miejscu doprecyzować, iż mamy tu na myśli osoby doświadczające niepełnosprawności (co wiąże się z posiadaniem orzeczenia potwierdzającego konkretny jej rodzaj), powstałej na wcześniejszych etapach życia, nie zaś te, które stały się niepełnosprawne $\mathrm{w}$ wyniku starzenia się $\mathrm{i} / \mathrm{lub}$ niepełnosprawność pojawiła się w tym okresie jako następstwo chorób czy przebytych urazów. W specyficznej sytuacji - i o takich osobach szczególnie myślimy - jest społeczność seniorów / starzejących się osób z niepełnosprawnością intelektualną, z zespołem Downa, które od dawna są beneficjentami dziennych placówek wsparcia (takich jak warsztaty terapii zajęciowej czy środowiskowe domy samopomocy). Wielu z nich to niejako zasiedziali podopieczni, niekiedy uczestniczący w zajęciach konkretnej placówki od samego jej powstania, czyli niekiedy nawet od blisko lat dwudziestu. Jest to bez wątpienia niezwykle istotne miejsce w biografii tych osób, a wielość doświadczeń związanych $\mathrm{z}$ tą lokalizacją jawi się w nieoceniona. Jednakże formuła wsparcia $w$ wymienionych placówkach wydaje się wyczerpana dla starzejących się ich podopiecznych, $\mathrm{w}$ jakiś sposób nawet nie tyle niewystarczalna, co po prostu nieodpowiednia na tym etapie ich życia. Wydaje się bowiem rozmijać z obecnymi potrzebami i możliwościami najstarszych podopiecznych.

Zasygnalizowana tu kwestia pozostaje również słabo rozpoznana jako przedmiot badań i opracowań naukowych. Podobnie jak obszar rozpoznawania w toku kształcenia pedagogów specjalnych, mimo iż Pedagogika specjalna już jakiś czas temu „przestała mieć status wyłącznie szkolnej pedagogiki specjalnej, kiedy jej zręby kształtowała Maria Grzegorzewska, a jej zadania realizowane są w wielu różnorodnych instytucjach także poza szkolnictwem" [Kupisiewicz 2016: 174]. Jak podkreśla M. Zaorska, nowe podejście do podmiotu zainteresowań pedagogiki specjalnej jest „zorientowane nie tyle na mechaniczne trenowanie umiejętności 
niezbędnych w przyszłym życiu (chociaż niewątpliwe jest ono znaczące), ile na stworzeniu osobie niepełnosprawnej warunków do decydowania o sobie, o własnym życiu, do samorealizacji i zdobycia wymaganego przygotowania do pełnienia różnych ról społecznych w dorosłości, aby człowiek z niepełnosprawnością mógł podjąć różne możliwe i wymagane role społeczne w perspektywie dorosłości, musi osiągnąć określony poziom funkcjonowania osobowościowego, fizycznego i społecznego" [Zaorska 2012: 14-15]

Zawód pedagoga specjalnego jest zawodem specyficznym. M. Kupisiewicz zalicza go do grupy zawodów podmiotowych, czyli takich, które nastawione są na pracę z drugim człowiekiem. Autorka podkreśla, iż ta profesja „poza przygotowaniem teoretycznym / merytorycznym o charakterze interdyscyplinarnym wymaga licznych kompetencji praktycznych, a także - a może przede wszystkim szczególnych predyspozycji wewnętrznych - osobowych, w tym charakterologicznych i empatycznych oraz pogłębionej świadomości moralno-etycznej" [Kupisiewicz 2016: 176-177].

Oczywiście zmiany w obszarze definiowania podmiotu pedagogiki specjalnej wymuszają zmianę podejścia do kształcenia pedagogów specjalnych przygotowywanych do pracy z osobami z niepełnosprawnością. Te wymagania oraz oczekiwania wobec profesji pedagoga specjalnego są bardzo duże, choć zawód pedagoga specjalnego „został ujęty w Klasyfikacji zawodów i specjalności na potrzeby rynku pracy oraz zakresu jej stosowania niedawno" [Kupisiewicz 2016: 174]. Rozporządzenie Ministra Pracy i Polityki Społecznej w tej właśnie sprawie weszło w życie z dniem 1 stycznia 2015 r.

Wśród paradygmatów charakteryzujących osobowość pedagoga specjalnego zaproponowanych przez K. Plutecką [2005] znalazł się m.in. paradygmat samoaktualizacji, który dobrze „wplata się” w przestrzeń nowych wyzwań, jakie niesie za sobą praca z osobami dorosłymi z niepełnosprawnością. Autorka samoaktualizację definiuje jako zasadniczy cel realizowania oraz wykorzystywania (w procesie rehabilitacyjnym) przez pedagoga specjalnego wszystkich swoich talentów, umiejętności oraz wiedzy w procesie rehabilitacyjnym. Podejmowanie przez pedagoga specjalnego „innowacyjnych, kreatywnych i samoaktualizujących się działań zależy od przygotowania specjalistycznego (czynników zewnętrznych) i moralnego (czynników podmiotowych)" [Plutecka 2005: 117]. Co ciekawe, w powyższej publikacji osobowość pedagoga specjalnego jest po prostu rozpatrywana tylko z perspektywy pedeutologicznej. Wspomniane zaś paradygmaty nazywa się po prostu paradygmatami pedeutologicznymi. Pedagog specjalny nie jawi się tu jako ktoś kto pracuje również z osobami dorosłymi.

Przemiany zachodzące w obszarze samej dyscypliny, jaką jest pedagogika specjalna, niewątpliwie znalazły swoje odzwierciedlenie w zmianach w zakresie kształcenia studentów na kierunku Pedagogika specjalna. Wiąże się to oczywiście 
z wdrażaniem w życie Krajowych Ram Kwalifikacji oraz podnoszeniem jakości kształcenia. Refleksja nad modelowymi strategiami pomocy osobom niepełnosprawnym znajduje się więc $\mathrm{W}$ ",ofercie" kształcenia przyszłych pedagogów specjalnych. Ta refleksja według M. Wilińskiego [2010: 61] skupia się na „,charakterystycznych dla poszczególnych strategii modelowych, uznanych i niekwestionowanych wewnętrznych założeniach, tj. na wydzieleniu ich, nazwaniu i możliwie precyzyjnym przedstawieniu w odwołaniu do bieżącej literatury i badań". Warto podkreślić, że jako obszar zaniedbany, niechciany i swoistego rodzaju nisza jawi się tu obszar wsparcia w dorosłości.

Zdaniem M. Zaorskiej [2012: 14-15] do zadań instytucji, które powołane są na rzecz pomocy w rozwoju dzieciom, młodzieży i dorosłym z niepełnosprawnością, a także środowisk, w których żyją osoby z niepełnosprawnością w różnym wieku, „należy poznanie możliwości podmiotów znajdujących się pod ich wpływem i określenie racjonalnych strategii realizacji zadań związanych $\mathrm{z}$ autonomizacją i samorealizacją tych podmiotów", przy czym "tak ujęte cele może zrealizować jedynie specjalista wykraczający w swojej pracy poza powszechnie przyjęte i często "utarte" przez lata standardy - twórczy/kreatywny, innowacyjny".

Jednym z powodów, który bezpośrednio wpłynął na głębsze zainteresowanie Pedagogiki specjalnej obszarem pracy z dorosłymi była niewątpliwie zmieniająca się rzeczywistość. Powstawanie w Polsce po 1992 r. pierwszych warsztatów terapii zajęciowej oraz pojawienie się po jakimś czasie środowiskowych domów samopomocy umożliwiło tworzenie zrębów systemu instytucjonalnego wsparcia dla dorosłych osób z niepełnosprawnością. Tworzenie z czasem rozwiązań z zakresu mieszkalnictwa oraz pracy (w tym zatrudnienia wspomaganego), a także realizacja różnych ofert i projektów w obszarze ekonomii społecznej, stworzyło możliwości wsparcia osób z niepełnosprawnością $\mathrm{w}$ wielu przestrzeniach ich życia.

Niewątpliwie jednak w polskim systemie wspierania dorosłych osób z niepełnosprawnością paradoks polega stale na tym, iż często „,sami niepełnosprawni są traktowani przez system albo jako klienci pomocy społecznej (muszą więc spełniać wymogi podyktowane przez ustawę o pomocy społecznej) albo traktowani są jako ewentualni kandydaci do pracy (muszą więc spełniać wymogi podyk- towane przez ustawę o rehabilitacji zawodowej i społecznej oraz zatrudnieniu osób niepełnosprawnych), a więc osoby, które muszą dowieść swojej przydatności do aktywności zawodowej" [Lindyberg 2009: 21]. Istotne byłoby, aby „zamiast tego ciągłego dopasowywania ludzi do programów i stawiania im zadań oraz formułowania celów wsparcia (a raczej rehabilitacji lub pomocy), które nie wynikają z rzeczywistych potrzeb i możliwości osoby, powinniśmy w większym stopniu tworzyć sieć wsparcia nieformalnego oraz dążyć do uzdrowienia obecnie funkcjonującej sieci społecznej" [Lindyberg 2009: 21].

Oczywiście idealnym rozwiązaniem powinno być takie, „w którym osoba niepełnosprawna lub jej przedstawiciel oraz jej najbliższe środowisko współdecy- 
dują o doborze usług i zasadach wspierania". Praktyka ujawnia jednak, że rzeczywistość bywa inna, bowiem osoba niepełnosprawna traktowana jest nadal jako przedmiot orzekania czy też działań naprawczych [Żółkowska 2011: 76].

W powyższym kontekście pojawia się oczywiste pytanie o wiedzę, umiejętności i kompetencje społeczne osób pracujących z dorosłymi z niepełnosprawnością: czy ukończenie studiów z zakresu pedagogiki specjalnej $\mathrm{w}$ tradycyjnej "odsłonie", a więc specjalności nauczycielskiej daje możliwości przygotowania studentów do pracy z dorosłymi osobami z niepełnosprawnością? Czy przygotowuje ich do wpierania takich osób w ich dorosłości? Czy daje możliwość poznania specyfiki tej pracy, w którą wpisują się nie tylko wyzwania metodyczne czy terapeutyczne, ale również liczne dylematy związane z dążeniem do tworzenia (na miarę możliwości) relacji symetrycznej?

Obszar przygotowania merytorycznego oraz metodycznego w tego typu pracy nawet w samym systemie jest traktowany "po macoszemu”. W zasadzie nie mamy do czynienia ze ściśle określonymi oczekiwaniami co do profilu osoby wspierającej $\mathrm{w}$ dorosłości osoby $\mathrm{z}$ niepełnosprawnością. Brakuje stosownych i szczegółowych zapisów w aktach prawnych normujących pracę tego typu placówek. W działaniach projektowych również spotykamy się z mało sprecyzowanymi wymaganiami dotyczącymi ewentualnych pracowników.

Jeśli chodzi o pracę $\mathrm{w}$ środowiskowych domach samopomocy (czyli w typie placówek określanych na mocy Ustawy o pomocy społecznej jako „ośrodki wsparcia"), to znajdujmy tam następujący zapis:

„§ 9 [3] 1. Kierownik domu jest obowiązany posiadać wykształcenie wyższe na kierunku mającym zastosowanie przy świadczeniu usług $\mathrm{w}$ domu oraz co najmniej półroczne doświadczenie zawodowe polegające na realizacji usług dla osób z zaburzeniami psychicznymi.

2. Do doświadczenia zawodowego, o którym mowa w ust. 1, zalicza się okres zatrudnienia $\mathrm{w}$ domu

§ 10.1 [4] W domu zatrudnia się, odpowiednio do potrzeb, osoby posiadające następujące kwalifikacje zawodowe:

1) psychologa;

2) pedagoga;

3) pracownika socjalnego;

4) instruktora terapii zajęciowej;

5) asystenta osoby niepełnosprawnej;

6) inne specjalistyczne, które będą odpowiadały rodzajowi i zakresowi usług świadczonych $w$ domu.

2. Dopuszcza się zatrudnienie pracowników realizujących świadczenia zdrowotne, w szczególności rehabilitacyjne i w zakresie opieki pielęgniarskiej, jeżeli potrzeby uczestników wskazują na konieczność codziennego świadczenia 
tych usług. 3. [5] W domu mogą być zatrudniani inni pracownicy, niezbędni do prawidłowego funkcjonowania domu.

$\S 11.1$ [6] Pracownicy, o których mowa w $§ 10$ ust. 1 i 2, są obowiązani posiadać co najmniej półroczne doświadczenie zawodowe polegające na realizacji usług dla osób z zaburzeniami psychicznymi".

(Rozporządzenie Ministra Pracy i Polityki Społecznej z dnia 9 grudnia 2010 r. w sprawie środowiskowych domów samopomocy").

Oczekiwanie ustawodawcy jest wiec takie, że pracownikiem może być osoba, która ukończyła pedagogikę, terapię zajęciową (może być to absolwent pomaturalnego studium terapii zajęciowej) lub asystent osoby niepełnosprawnej. Warto zwrócić uwagę, iż nie ma tu żadnego wymogu dotyczącego zatrudnienia pedagoga specjalnego. Pracować w środowiskowym domu samopomocy może absolwent dowolnej specjalności z zakresu pedagogiki.

Nieco odmienna sytuacja jest $\mathrm{w}$ warsztatach terapii zajęciowej. Zapis $\mathrm{w}$ rozporządzeniu normującym pracę $w$ tego typu placówce dotyczący wymogów odnoszących się do wykształcenia ewentualnych pracowników i jest następujący:

„§ 13. 1. Pracownikami warsztatu są:

1) kierownik warsztatu;

2) 3) instruktorzy terapii zajęciowej

4) psycholog.

2. W zależności od potrzeb $\mathrm{w}$ warsztacie zatrudnia się:

1) pielęgniarkę lub lekarza,

2) pracownika socjalnego,

3) instruktora zawodu,

4) inne osoby niezbędne do prawidłowego funkcjonowania warsztatu". (Rozporządzenie ministra gospodarki, pracy i polityki społecznej w sprawie warsztatów terapii zajęciowej z 25.03.2004 r.).

W kontekście powyższego zapisu pedagog specjalny to ów "specjalista do spraw rehabilitacji lub rewalidacji". Owym specjalistą może więc być osoba, która ukończyła studia z zakresu pedagogiki specjalnej, nawet wtedy gdy tą specjalnością jest na przykład: „edukacja osób z niepełnosprawnością intelektualną” (a więc specjalność nauczycielska). Nie ma wymogu przygotowania do pracy $\mathrm{z}$ dorosłymi osobami $\mathrm{z}$ niepełnosprawnością. $\mathrm{W}$ rozporządzeniu normującym pracę środowiskowych domów samopomocy jest chociaż niewielka wzmianka dotycząca przeszkolenia oraz doświadczenia w obszarze takiej pracy:

„\$11. 2. Pracownicy, których zakres obowiązków obejmuje prowadzenie treningów umiejętności społecznych, są obowiązani posiadać przeszkolenie i doświadczenie w zakresie:

1) umiejętności kształtowania motywacji do akceptowanych przez otoczenie zachowań; 
2) kształtowania nawyków celowej aktywności;

3) prowadzenia treningu zachowań społecznych." ( Rozporządzenie ministra pracy i polityki społecznej z dnia 9 grudnia 2010 r. w sprawie środowiskowych domów samopomocy."

Puentujac powyższe fakty dość powiedzieć, że w systemie instytucjonalnego wparcia dorosłych osób z orzeczonym stopniem niepełnosprawności brakuje szczegółowych wymagań co do profilu osoby pracującej z dorosłymi osobami z niepełnosprawnością, zaburzeniami rozwojowymi czy doświadczającymi choroby. Student kierunku: Pedagogika specjalna, który w przyszłości chciałby pracować z dorosłymi, może wybrać specjalność nauczycielską i ma szansę po skończeniu studiów otrzymać pracę w tego typu placówkach. Należy nadmienić, że w toku kształcenia na uczelni wyższej student studiów licencjackich pozna zagadnienia dotyczące wsparcia $\mathrm{w}$ dorosłości $\mathrm{w}$ szczątkowej formule, np. podczas wykładów w wymiarze 20 lub 30 godzin. Jest to absolutny paradoks, który niestety ma swoje konsekwencje nie tylko dla indywidualnego wspierania osób z niepełnosprawnością, ale również dla budowania i tworzenia tego systemu. Zdajemy sobie sprawę, iż od roku akademickiego 2018/2019 wchodzą w życie zapisy nowej ustawy jaką jest Konstytucja dla Nauki (Ustawa z dnia 20 lipca 2018 r. - Prawo o szkolnictwie wyższym i nauce), a wraz z nią zainicjowane zostaną przemiany w obszarze kształcenia pedagogów specjalnych. Jedną z zasadniczych zmian jest powrót do pięcioletnich studiów magisterskich, jednak trudno na tym etapie ostatecznie powiedzieć, $\mathrm{w}$ jaki sposób zostaną zaprojektowane na poszczególnych uczelniach, w tym także w ośrodku akademickim, który reprezentujemy. Projekt oferty kształcenia na pedagogice specjalnej jest bowiem $\mathrm{w}$ procesie tworzenia, by ostatecznie przyjąć kształt właściwy tak indywidualnemu konceptowi naszej jednostki w Uniwersytecie Gdańskim, jak i w oczywisty sposób wypełniać wszelkie ustawowe wymogi. Zanim jednak rozpocznie się rekrutacja studentów na pierwsze roczniki pięcioletnich (jednolitych) studiów magisterskich na pedagogice specjalnej, kształcenie realizować będą "ostatnie" roczniki już odbywające studia $\mathrm{w}$ cyklu: licencjat i/lub magisterskie studia uzupełniające. Zatem nadal pozostaje aktualne pytanie o to jakie miejsce już zajmuje w „starej” formule kształcenia pedagogów specjalnych, a w jaki sposób zostanie wytyczona ta część studiów pięcioletnich magisterskich, podczas których student pedagogiki specjalnej pozna i przygotuje się do podjęcia w przyszłości pracy w placówkach dla dorosłych osób z niepełnosprawnością.

Wywodząc naszą wypowiedź $\mathrm{w}$ tym artykule $\mathrm{z}$ praktyki prowadzenia studiów i zajęć ze studentami w naszym ośrodku akademickim konstatujemy, iż $\mathrm{w}$ stosunku do całego cyklu kształcenia (licencjat i/lub studia magisterskie uzupełniające) na tzw. "dorosłość z niepełnosprawnością" jako obligatoryjny przedmiot poświęca się jeden wykład konwersatoryjny $\mathrm{w}$ wymiarze nieprzekraczającym 
30 godzin (studia licencjackie) oraz ćwiczenia obejmujące 20-30 godzin dedykowane dorosłym osobom ze spektrum autyzmu na studiach magisterskich uzupełniających, realizowany na specjalności zaprojektowanej z myślą o osobach z autystycznego spektrum zaburzeń.

A. Krause [2016: 14] nie tylko zauważa ten paradoks, ale czyni pewną generalizację, gdy odnosi się do współczesnego kształcenia oligofrenopedagogów w ogólniejszym wymiarze: „W polskich uczelniach kształcenie oligofrenopedagogów, z małymi wyjątkami, ogranicza się do edukacji i rehabilitacji dziecka niepełnosprawnego. Nieliczne próby utworzenia specjalizacji przygotowania do pracy z dorosłymi nie cieszą się dużym zainteresowaniem studentów. Przyczyną są najprawdopodobniej uregulowania prawne dotyczące pracy z dorosłą osobą niepełnosprawną, a w zasadzie ich brak. Do pracy z osobą dorosłą z niepełnosprawnością intelektualną zatrudniane są osoby po tradycyjnej oligofrenopedagogice, bez względu na to, że są to studia przygotowujące do edukacji dziecka z niepełnosprawnością intelektualną. Student wybierając tą specjalność ma zarówno możliwość pracy w szkole (regulowane standardami kształcenia), jak i we wszystkich pozostałych placówkach". Warto w tym miejscu również nadmienić, iż w literaturze źródłowej niewiele jest publikacji poświęconych „specjalistom od dorosłości z niepełnosprawnością"; terapeutom, pedagogom różnych specjalności czy osobom reprezentującym inne profesje, którzy aktywnie pracują w rozmaitych placówkach/instytucjach w obszarze wsparcia w dorosłości. Pewne głosy dotykające wymienionej problematyki odnaleźć można w tekstach autorstwa M. Granosika [1997], D. Krzemińskiej [2012, 2015], A. Woynarowskiej [2017], A. Woynarowskiej i J. Rzeźnickiej-Krupy [2014].

\section{Ku nowej jakości w przygotowaniu profesjonalistów do pracy w obszarze dorosłości z niepełnosprawnością czyli nowa (torska) specjalność w ofercie studiowania na kierunku pedagogika specjalna}

Znając specyfikę pracy z dorosłymi osobami z niepełnosprawnością oraz realia systemu wsparcia tej grupy osób, w Zakładzie Pedagogiki Specjalnej UG, a ściślej mówiąc w istniejącej wówczas Pracowni Badań nad Niepełnosprawnością w Dorosłości, narodził się pomysł uruchomienia na kierunku Pedagogika specjalna specjalności na studiach drugiego stopnia, która miałaby przygotowywać studentów do pracy z osobami dorosłymi (ze szczególnym uwzględnieniem osób w podeszłym wieku) z niepełnosprawnością.

Początkowo, pierwsze dwie edycje tej specjalności nosiły nazwę: „Rehabilitacja społeczna i zawodowa z doradztwem", ale z czasem, wraz ze wzbogaceniem 
oferty o terapię zajęciową, nazwa ta została przeformułowana na "Rehabilitacja i wsparcie w dorosłości z terapią zajęciową".

Przedmioty specjalnościowe, które ostatecznie pojawily się na tej specjalności w planie studiów, były następujące:

- diagnoza potrzeb osoby dorosłej (30 godzin na studiach stacjonarnych i 30 godzin na studiach niestacjonarnych);

- metodyka pracy z osobą dorosłą z niepełnosprawnością/ praca z dorosłą osobą z niepełnosprawnością dorosłej (30 godzin na studiach stacjonarnych i 20 godzin na studiach niestacjonarnych);

- wsparcie w dorosłości osób niepełnosprawnych dorosłej (30 godzin na studiach stacjonarnych i 20 godzin na studiach niestacjonarnych);

- wsparcie w pracy i doradztwo zawodowe dla osoby dorosłej z niepełnosprawnością dorosłej (45 godzin na studiach stacjonarnych i 35 godzin na studiach niestacjonarnych);

- zagadnienia gerontologiczne w pedagogice specjalnej dorosłej (15 godzin na studiach stacjonarnych i 10 godzin na studiach niestacjonarnych);

- podstawy terapii zajęciowej dorosłej (15 godzin na studiach stacjonarnych i 10 godzin na studiach niestacjonarnych);

- metody terapii zajęciowej dorosłej (30 godzin na studiach stacjonarnych i 20 godzin na studiach niestacjonarnych);

- praktyka specjalnościowa (20 godzin na studiach stacjonarnych i 20 godzin na studiach niestacjonarnych).

Należy jednak podkreślić, że w grupie przedmiotów kierunkowych, które poprzedzały wprowadzenie przedmiotów specjalnościowych, znajdowały się również dwa przedmioty, które stanowily istotną podbudowę dla realizacji bloku zajęć specjalnościowych. Był to wykład z przedmiotu: „Polityka społeczna i wsparcie osób niepełnosprawnych" (30 godzin na studiach stacjonarnych i 20 godzin na studiach niestacjonarnych) oraz przedmiot realizowany $\mathrm{w}$ formule konwersatorium: „Promocja aktywności i organizacje pozarządowe na rzecz niepełnosprawności" (25 godzin na studiach stacjonarnych i 20 godzin na studiach niestacjonarnych).

Ważnym elementem kształcenia studentów były również celowo zaprojektowane i odpowiednio wkomponowane $\mathrm{w}$ cały cykl kształcenia zajęcia $\mathrm{w}$ terenie, realizowane jako hospitacje (obserwacja uczestnicząca) oraz podejmowane przez studentów próbki badawcze, które w maksymalnym zakresie miały udostępnić im praktyczne doświadczanie poznawanego obszaru, wraz z pogłębionym nad nim namysłem i analizą.

Z proponowanej studentom do wyboru opisanej powyżej specjalności (obok możliwych alternatywnych propozycji specjalności: Wczesne wspomaganie rozwoju oraz Edukacja i rehabilitacja osób z autystycznego spektrum zaburzeń) zrea- 
lizowane zostały zaledwie cztery cykle/roczniki. Oznacza to, że jedynie w ciągu czterech kolejnych naborów na specjalności studenci (zarówno studiów stacjonarnych, jak i zaocznych) wybrali "naszą" specjalność, ustanawiając grupę na tyle liczebną, iż umożliwiła ona uruchomienie rocznika. Trzy ostatnie lata wskazują, że liczba osób chętnych do podjęcia studiów na specjalności Rehabilitacja i wsparcie w dorosłości jest tak znikoma, iż nie umożliwia zawiązania się grupy.

\section{Próba refleksji w kontekście teoretycznym: wokół metafory "nie-miejsca”}

Nakreślony przez nas powyżej kontekst rozważań, w którym dzielimy się doświadczeniem związanym z kwestią nie dokonywania przez studentów wyboru specjalności Rehabilitacja i Wsparcie w dorosłości z terapią zajęciową, pozwala, by spojrzeć na ten problem w odniesieniu do propozycji Marca Auge i jego koncepcji nie-miejsc(a). Wedle słów wymienionego autora [2011: 53] „Jeśli jakieś miejsce można definiować jako tożsamościowe, relacyjne i historyczne, to przestrzeń, której nie można zdefiniować ani jako tożsamościowej, ani jako relacyjnej, ani jako historycznej definiuje nie-miejsce [...]. Miejsce i nie-miejsce są raczej ulotnymi biegunami - pierwszy nigdy całkowicie się nie zatarł, drugi nigdy się nie dopełnia $[\ldots] "$.

Jednym ze sposobów egzemplifikacji i konkretyzacji (wyobrażenia) nie-miejsca jest objaśnienie, które wyczytujemy z tekstu Auge, iż nie-miejsce jawi się „[...] policzalną miarą, którą można obliczyć, dodając do siebie - za ceną kilku konwersji między powierzchnią, objętością i odległością - trasy powietrzne i kolejowe, ruchome przybytki zwane "środkami transportu" (samoloty, pociągi, samochody), porty lotnicze, dworce i stacje kosmiczne, wielkie sieci hoteli, wesołe miasteczka, supermarkety, skomplikowane węzły komunikacyjne, wreszcie - sieci kablowe lub bezprzewodowe działające $\mathrm{w}$ przestrzeni pozaziemskiej i służące tak dziwnej komunikacji, że łączy ona jednostkę wyłącznie z innym obrazem jej samej".

Zacytowany powyżej obszerny fragment tekstu Auge na pierwszy rzut oka może podawać $w$ wątpliwość i kwestionować zasadność próby jego zastosowania i referowania do prezentowanych $\mathrm{w}$ naszym artykule rozważań. Postaramy się jednakże przedstawić argumentację i przekonać, że zastosowana tutaj figura "nie-miejsca" wydaje się możliwa do zaaplikowania w kontekście dyskusji o (niedostatku, by nie powiedzieć braku) profesjonalnej formacji osób, które rolę zawodową wiążą z obszarem wsparcia dorosłych i seniorów z niepełnosprawnością. Przykład zaś „pomijania” oferty, jaką stanowi specjalność na kierunku Pedagogika specjalna na naszej uczelni, skłania nas w rezultacie namysłu i refleksji do sfor- 
mułowania pewnych konkluzji. Odnoszą się one nie tylko $w$ dostrzeżeniu istotnej luki w obszarze kształcenia wyższego, związanego z przygotowaniem zawodowym profesjonalistów, do pracy w przedmiotowej dziedzinie. Ów brak wyboru wymienionej specjalności jawi się nam jako możliwa pochodna m.in. aktualnych rozwiązań ustawodawczych, które zarówno nie precyzują szczegółowo, jakimi kompetencjami (w kontekście wiedzy i umiejętności praktycznych potwierdzonych odpowiednimi certyfikacjami) powinna legitymować się osoba podejmująca pracę $\mathrm{w}$ obszarze wsparcia dorosłych osób z niepełnosprawnością, w konkretnych instytucjach realizujących wymienioną działalność. Ujmując swoiste ignorowanie $w$ wyborach dokonywanych przez studentów specjalności rehabilitacja i wsparcie w dorosłości z terapią zajęciową jako traktowanie jej „po macoszemu" skłaniamy się ku konstatacji, iż zawodowa formacja kadry do tego obszaru działań i w relacji z konkretną grupą osób wspieranych nie jest objęta należytą uwagą nie tylko ustawodawcy, z niepełnosprawnością oraz rozwiązań $\mathrm{w}$ polu codziennych, instytucjonalnych praktyk ( $w$ ramach rehabilitacji zawodowej i społecznej).

Trudno jakkolwiek jednoznacznie zaprzeczyć, że problematyka dorosłości $\mathrm{z}$ niepełnosprawnością jest całkowicie pomijana w toku edukacji realizowanej na studiach licencjackich czy magisterskich $\mathrm{w}$ dyscyplinie pedagogiki specjalnej. Podobnie jak oczywisty jest fakt, że od ponad ćwierćwiecza na polskiej mapie (oddziaływań w zakresie) wsparcia i rehabilitacji zawodowej oraz społecznej dorosłych osób niepełnosprawnych funkcjonują placówki realizujące wymienioną działalność. W tym sensie obszar wsparcia w dorosłości niepełnosprawnych wraz z siecią właściwych dlań instytucji i dokonujących się w nich działań - jeśli przywołać definicję M. Auge - jawi się może jako miejsce tożsamościowe, relacyjne i historyczne. A więc takie, które ma swoje ukorzenienie w istniejących przepisach i regulacjach prawnych, realizowane jest zgodnie z określonymi wytycznymi i procedurami oraz wiąże się z konkretną grupą podmiotów, pomiędzy którymi kształtują się właściwe dla pełnionych ról relacje. Są to osoby z niepełnosprawnością korzystające $w$ oferty wsparcia i rehabilitacji realizowanej w powołanych do tego instytucjach oraz pracujący z nimi specjaliści, którzy w założeniu legitymują się wymaganym $\mathrm{w}$ danym miejscu przygotowaniem (zawodowym). To jednak bliższe przyjrzenie się wymienionym swoistym trzem zakresom $\mathrm{w}$ obszarze wsparcia dorosłych i seniorów a niepełnosprawnością - przygotowania/formacji zawodowej specjalistów oraz związane z tym regulacje ustawodawcze określające wymagania formalne do pracy w omawianym obszarze, jak również aktualna oferta dla tegoż - wydobywa na jaw zauważalne niedostatki i/lub braki, które z kolei skłaniają do tego, by na wsparcie i rehabilitację (zawodową i społeczną) tej grupy spojrzeć przez pryzmat nie-miejsca. Jest ono bowiem metaforą czegoś, co 
$\mathrm{w}$ jakimś sensie istnieje i jest realne, ale zarazem wykazuje cechy niedookreśloności, ulotności, niczego stałego i na trwałe osadzonego w danej przestrzeni.

Z jednej strony bowiem, kształcąc studentów na kierunku Pedagogika specjalna - zarówno na studiach pierwszego, jak i drugiego stopnia zyskują oni wiedzę, umiejętności i kompetencje (społeczne) związane ze zjawiskiem niepełnosprawności oraz problematyką osób niepełnosprawnych oraz poznają właściwe dla danej niepełnosprawności metody pracy (terapii, rehabilitacji, wsparcia). Z drugiej jednak strony obszar owego zawodowego znawstwa pomija przygotowanie konkretnie i ściśle dedykowane dorosłym i seniorom z niepełnosprawnością. Formacja do zadań związanych z tym obszarem ogranicza się zwykle do pojedynczych przedmiotów (np. na studiach licencjackich jest to zaledwie 30 bądź 20 godzin wykładu wprost i celowo dedykowanego pracy z dorosłymi osobami z niepełnosprawnością intelektualną. Wymieniony jeden wykład (w połączeniu z całym cyklem studiów skoncentrowanych jednak na przygotowaniu do podjęcia pracy w placówkach obejmujących działania związane z realizacją obowiązku edukacyjnego / w placówkach edukacyjno-rehabilitacyjnych) stanowi wystarczający cenzus, by - posiadając już dyplom licencjata - podjąć pracę związaną ze wsparciem i rehabilitacją dorosłych i seniorów z niepełnosprawnością. Podobnie jak w odwołaniu do przepisów prawa taką pracę wykonywać może np. w środowiskowych domach samopomocy osoba $\mathrm{w}$ ogóle nieposiadająca żadnego przygotowania kierunkowego $\mathrm{w}$ dyscyplinie pedagogiki specjalnej, a za wystarczające uznaje się ukończony kurs z zakresu terapii zajęciowej. Ta zresztą umiejscowiona jest poza naukami społecznymi i humanistycznymi, i od lat przynależy do obszaru nauk medycznych, co nie pozostaje bez znaczenia dla ostatecznego zorientowania i osadzenia absolwentów takich kursów, jeśli chodzi o ich źródłową wiedzę, praktyczne umiejętności i społeczne kompetencje.

O tym, w jaki sposób będzie przedstawiało się kształcenie pedagogów specjalnych na pięcioletnich magisterskich studiach, które zostaną zainicjowane od następnego roku akademickiego, trudno w tej chwili mówić jako o domkniętym projekcie, gdyż jest on w trakcie przygotowywania. Sądzimy, że to właściwy moment na poddanie pod namysł i ewentualne rozstrzygnięcia w kontekście wkomponowania "dorosłości z niepełnosprawnością" w na nowo inicjowanych jednolitych pięcioletnich studiach magisterskich na kierunku pedagogika specjalna.

Fakt, który jednak odnotowujemy w ostatnich latach w tym obszarze kształcenia, wyraźnie wskazuje, że studenci nie wybierają specjalności Rehabilitacja i wsparcie $\mathrm{w}$ dorosłości z terapią zajęciową. Sam zaś przedmiot na studiach pierwszego stopnia o nazwie Praca z dorosłą osobą z niepełnosprawnością intelektualną realizowany na studiach pierwszego stopnia na kierunku pedagogika specjalna na specjalności oligofrenopedagogika z terapią pedagogiczną, większość studentów nie traktuje jako „swój”" przedmiot, gdyż nie widzą siebie w pracy z dorosłymi 
w dedykowanych im placówkach. Zjawisko to można interpretować na kilka sposobów, które w naszym rozumieniu sytuują obszar wsparcia dorosłych osób z niepełnosprawnością, przygotowania właściwych i profesjonalnie, w pełni kompetentnych kadr dysponujących obszerną wiedzą i rozeznaniem przedmiotowym w kategorii nie-miejsca. Czegoś co kolokwialnie ujmując "trochę jest”, ale niezupełnie, niby znajduje konkretną pozycję w planie kształcenia studentów, ale jednocześnie nie jest to umiejscowienie na tyle znaczące w całym cyklu studiów na kierunku pedagogika specjalna, by wyraźnie zakreślać istotną ścieżkę w profilu kształcenia. I konsekwentnie wiązać się ze zdobyciem starannego oraz kompletnego przygotowania do pracy właśnie z osobami dorosłymi i seniorami, którzy trwale doświadczają niepełnosprawności. Tym samym (nie)studiowanie obszaru dorosłości jawi się nam jako nie-miejsce: kontekst, który w jakimś sensie ma swój tożsamościowy, onegdaj ukształtowany rys, ale jednocześnie nie legitymuje się istotnym otwarciem ku i tworzeniem nowej jakości, bardziej adekwatnej i spójnej z wyraźnie zarysowującymi się aktualnymi potrzebami i wymaganiami w polu dorosłości splecionej z niepełnosprawnością i jej wsparciem. Nawiązując do myśli M. Auge nie-miejsce staje się czymś chwilowym, nieugruntowanym, znaczonym równie chwilową obecnością, która ponadto nie wiąże się z zagłębieniem się weń z uwagą i wnikliwością. Nie-miejsce ledwie dotykamy, muskamy powierzchownie, ulotnie, bez zasiedzenia i zakorzenienia $\mathrm{w}$ nim.

Zatrzymujemy się na chwilę, realizując doraźną konieczność, lecz nie ma ono charakteru trwałego i długofalowego. Niczym podróżny pobieżnie przemierzający obiekt dworca czy lotniska - nie związany z tym obiektem ani chwilę dłużej, niż wymaga tego przemieszczenie się pomiędzy określonymi lokalizacjami wojażu, który odbywa. Podobnie w naszym odczuciu ma się rzecz związana z pochyleniem się i faktycznym rozpoznaniem wiodącym ku zbudowaniu możliwie najpełniejszej wiedzy o specyfice dorosłości i starzenia się splecionego $\mathrm{z}$ niepełnosprawnością oraz uzyskaniem kompetencji do udzielania profesjonalnego, o wysokiej jakości wsparcia, opartego na znajomości bogatego repertuaru możliwych dróg i sposobów działania.

Studenci studiów licencjackich z pedagogiki specjalnej zyskują raczej rodzaj preorientacji, wstępnego, elementarnego, wręcz na zupełnie podstawowym poziomie, poznania wymienionego obszaru i zjawisk związanych z etapem dorosłego życia oraz starzenia się i starości z niepełnosprawnością, a także adekwatnego w tym czasie wsparcia. W naszym gdańskim ośrodku, o czym piszemy powyżej, studenci studiów magisterskich - o ile wybiorą specjalność związaną w edukacją i rehabilitacją osób autystycznych - zrealizują 30 godzin ćwiczeń z przedmiotu dedykowanego „pracy z dorosłymi”. Owa nikła wiedza i orientacja $\mathrm{w}$ polu działań $\mathrm{z}$ dorosłymi i seniorami nie wzbudza w konsekwencji zainteresowania tym etapem ludzkiej egzystencji uwikłanej w niepełnosprawność, a tym 
samym nie wyzwala chęci jej bliższego poznania i uzyskania kompetencji do profesjonalnych działań. Być może nawet ta „śladowa” postać zajęć w toku studiów dedykowanych wymienionej problematyce dodatkowo wzbudza i ugruntowuje przekonanie, że obszar dorosłości/starości z niepełnosprawnością i zawodowego wsparcia na tym etapie życia człowieka nie jest wart (aż takiej) uwagi, a co więcejnie wymaga zdobycia odpowiednich kompetencji i kwalifikacji, by podjąć pracę z dorosłymi i seniorami, zapewniając jej optymalną jakość.

Odwołując się do doświadczeń związanych z realizacją zajęć ze studentami możemy powiedzieć, że ci wprost podają, iż nie widzą siebie „w pracy z dorosłymi"; niektórzy z nich z pewnym lękiem, a w każdym razie z wyraźnym dystansem myślą o dorosłych osobach z niepełnosprawnością, szczególnie w odniesieniu do tych z głębszym jej stopniem, z głębszą i głęboką niepełnosprawnością intelektualną czy z niepełnosprawnością wieloraką, sprzężoną. Jednocześnie wskazują, że w toku kształcenia (np. w doświadczeniu studentów studiów licencjackich na pedagogice specjalnej o specjalności: oligofrenopedagogika z terapią pedagogiczną) nie mieli oni kontaktów z dorosłymi osobami z niepełnosprawnością intelektualną, a ich obowiązkowe praktyki realizowane były w placówkach szkolnych.

W takim kontekście „studiowanie dorosłości z niepełnosprawnością” jawi się nam jako nie-miejsce, czyli przestrzeń, która bywa „(roz)poznana" wyłącznie ulotnie - „przelotem”, jako jeden z przedmiotów $\mathrm{w}$ ",siatce" studiów i to właściwie przedmiot jedyny, zatem poznaje się go jedynie na chwilę, by potem przenieść się w inny obszar i być może na nim skupić większą uwagę, traktując go jako „miejsce swoiście docelowe". Dorosłość z niepełnosprawnością i jej wsparcie w polu działań i relacji z konkretnymi podmiotami zdaje się nie dość dostatecznie osadzona i wyrażona w konkretnych przedmiotach w planie studiów: licencjackich, a jeśli jej studiowanie staje się jedną z możliwych ofert do wyboru jako specjalność na studiach magisterskich, to grupa studentów, która decyduje się na ten wybór, jest tak nieliczna, że nie pozwala na „uruchomienie” tej specjalności. W tym znaczeniu rehabilitacja i wsparcie w dorosłości z terapią zajęciową stają się metaforą nie-miejsca: czegoś, co istnieje, ale zarazem - w rozumieniu i kontekście studenckich wyborów nie ma wyraźnej tożsamości, ani też nie wydaje się czymś, co w sposób klarowny definiuje jej „historyczną i relacyjną przestrzeń".

Nie sposób nie ulec wrażeniu, iż kolejny rocznik podejmujący kształcenie na kierunku Pedagogika specjalna na drugim studiów stopniu "omija” specjalność Rehabilitacja i wsparcie $\mathrm{w}$ dorosłości z terapią zajęciową, a ta przegrywa wybory w konkurencji ze specjalnościami: Edukacja i terapia osób z autystycznego spektrum zaburzeń oraz Wczesne wspomaganie rozwoju dzieci z niepełnosprawnością. Te bowiem specjalności są oblegane, gdyż - jak przypuszczamy - stanowią, w odróżnieniu od nie-miejsca, właśnie owo miejsce, czyli bezpieczną przestrzeń, 
w której studenci mogą odnaleźć się w polu działań z dziećmi i ewentualnie młodzieżą szkolną. Ta grupa wiekowa wydaje się bardziej bliska, swojska i rozpoznane $w$ toku dotychczasowych trajektorii kształcenia na studiach z pedagogiki (specjalnej), a tym samym jawi się jako pole zdefiniowane „tożsamościowo, historycznie i relacyjnie". W rozumieniu M. Auge jest miejscem - lokacją do zakorzenienia, w której się bytuje, egzystuje, w której się jest. Pojęcia „edukacja”, ,"terapia”, , „dzieci" wydają się dla studentów bliższe i w jakiś sposób przewidywalne, jeśli chodzi o antycypacje własnej pracy i podmiotu tejże, a wyraźne tendencje w wyborach specjalności na drugim stopniu studiów na Pedagogice specjalnej wydają się potwierdzać dość ugruntowaną pozycję dominacji treści kształcenia skoncentrowanych na edukacji i wychowaniu. Pełniejsze potwierdzenie naszych wstępnych przypuszczeń dotyczących studenckich wyborów - ich motywów, znaczeń jakie studenci nadają sobie i wyobrażeniu przyszłej pracy zawodowej, również w potencjalnym kontekście wsparcia dorosłych z niepełnosprawnością - wskazują ważny i ciekawy kierunek ewentualnych celowo zaprojektowanych badań.

Tymczasem aspirujemy do tego, by prezentowany przez nas tekst był głosem upominającym się o to, by „opieka w dorosłości jako odkrycie rewalidacyjne XXI wieku" - tu posiłkujemy się określeniem A. Krause [2011: 50] - zyskała należną jej rangę w polu działań polityki społecznej, kompleksowego systemu rehabilitacji i wsparcia oraz ustawodawczych, które w konsekwencji znajdą przełożenie na konkretne zmiany $\mathrm{w}$ obszarze przygotowania zawodowego kadr podejmujących pracę z osobami dorosłymi z niepełnosprawnością. Wydaje się nam, że „widoczny od lat dystans, jaki dzieli działania i inicjatywy rehabilitacyjne od akademickich ośrodków generujących koncepcje i podłoże teoretyczne, przyczynia się do różnego pojmowania optymalizacji drogi ku dorosłości" [Krause 2011: 51]. Ową optymalizację upatrujemy także jako rekonstrukcję akademickiego kształcenia profesjonalistów - pedagogów specjalnych, których formacja zawodowa będzie ściśle związana z konkretną ścieżką edukacji (na poziomie wyższym) w zakresie przygotowania do opieki i wsparcia w dorosłości/starości z niepełnosprawnością. Nie idzie tu bowiem li tylko o projekt „osobnych” specjalności (choć uznajemy takie rozwiązanie za korzystną możliwą do wyboru ofertę) na pięcioletnich studiach magisterskich z pedagogiki specjalnej - bo to one zaistnieją na nowo od najbliższej rekrutacji. Natomiast z całą mocą akcentujemy potrzebę uwzględnienia przygotowania do pracy z dorosłymi osobami z niepełnosprawnością jako istotnej części cyklu kształcenia w ogóle. Istotność ta znajdzie swoje urealnienie $w$ należycie skonstruowanej całości zajęć, nie zredukowanej bynajmniej do jednego przedmiotu, ale stanowić będzie komponent (np. kilku obligatoryjnych przedmiotów i obszerniejszej niż dotąd liczby godzin). Jawi się to, jak sądzimy, możliwe do zrealizowania podczas aktualnie toczących się działań związanych z tworzeniem nowych "siatek" studiów na pedagogice specjalnej, które obowiązywać będą od nadchodzącego roku akademickiego. 


\section{Bibliografia}

Auge M. (2011), Nie-miejsca. Wprowadzenie do antropologii hipernowoczesności, Wydawnictwo Naukowe PWN, Warszawa.

Granosik M. (1997), Niektóre aspekty pracy nad rozumieniem upośledzonego, „Studia Socjologiczne", vol. 144.

Kupisiewicz M. (2016), Pedagog specjalny - człowiek o wyjątkowych predyspozycjach osobowościowych, profesjonalista posiadający rozległa, interdyscyplinarna wiedzę i umiejętności, "Studia z Teorii Wychowania", t. 7, nr 4(17).

Krause A. (2016), Dorosłość w niepetnosprawności intelektualnej, „Niepełnosprawność. Dyskursy Pedagogiki Specjalnej", nr 24.

Krause A. (2011), Wspótczesne paradygmaty pedagogiki specjalnej, Oficyna Wydawnicza „Impuls", Kraków.

Krzemińska D. (2014), Style bycia/działania terapeutów jako asumpt do rozważań o placówkach wsparcia dorostych osób z głębsza niepetnosprawnościa intelektualną, "Niepełnosprawność. Dyskursy Pedagogiki Specjalnej", nr 16.

Krzemińska D. (2012), Dorośli z niepetnosprawnościa w okowach "misji rehabilitacyjnej” - perspektywa postkolonialna [w:] D. Krzemińska, I. Lindyberg, Wokót dorostości z niepetnosprawnością intelektualną. Teksty rozproszone, Oficyna Wydawnicza „Impuls”, Kraków.

Lindyberg I. (2009), Pytanie o specyfikę systemu instytucjonalnego wsparcia dorostych osób z niepetnosprawnościa, „Niepełnosprawność. Życie z niepełnosprawnością. Trud dorastania i społecznej egzystencji", $\mathrm{nr} 2$.

Marzenna Z. (2012), Rola i miejsce pedagoga specjalnego w kreowaniu działalności edukacyjno-terapeutycznej, Acta Universitatis Nicolai Copernici, Pedagogika XXVIII, Nauki Humanistyczno-Społeczne, z. 405.

Plutecka K. (2005), Obraz pedagoga specjalnego w aspekcie nowoczesnych paradygmatów pedeutologicznych, „Szkoła Specjalna”, nr 2.

Rozporządzenie Ministra Pracy i Polityki Społecznej z dnia 9 grudnia 2010 r. w sprawie środowiskowych domów samopomocy.

Rozporządzenie Ministra Gospodarki, Pracy i Polityki Społecznej z dnia z 25 marca 2004 r. w sprawie warsztatów terapii zajęciowej.

Wiliński M. (2010), Diagnoza potrzeb i modele pomocy dla osób z ograniczeniami sprawności, A. Brzezińska, R. Kaczan, K. Smoczyńska (red.), Warszawa.

Woynarowska A. (2017), Być terapeutą dorostych osób z niepetnosprawnościa intelektualną. Rozważania o dorosłości z niepetnosprawnościq intelektualna i jej wsparciu, „Niepełnosprawność. Dyskursy Pedagogiki Specjalnej", nr 25.

Woynarowska A., Rzeźnicka-Krupa J. (2014), Znaczenia nadawane wsparciu w dorosłości i własnej w nim roli przez terapeutów dorostych osób z niepetnosprawnościa intelektualną, "Niepełnosprawność. Dyskursy Pedagogiki Specjalnej", nr 16

Żółkowska T. (2011), Wspomaganie rozwoju dorostych osób z niepetnosprawnościa intelektualnq refleksje pedagoga [w:] Dorośli z niepetnosprawnościa intelektualna w labiryntach codzienności Analiza badań - krytyka podejść - propozycje rozwiązań, B. Cytowska (red.), Torun. 